\title{
Worth the Wait? Using Past Patterns to Determine Wait Periods for E-books Released after Print
}

\author{
Karen Kohn
}

This paper asks if there is an optimal wait period for e-books that balances libraries' desire to acquire books soon after their publication with the frequent desire to purchase books electronically whenever feasible. Analyzing 13,043 titles that Temple University Libraries received on its e-preferred approval plan in 2014-15, the author looks at the delays from the publication of print books to publication of their electronic versions. The analysis finds that most books on the approval plan are published electronically within a week of the print. Recommended wait periods are provided for different subjects.

\section{Introduction}

As more academic books are published electronically, ${ }^{1}$ e-book purchasing is becoming a larger part of library acquisitions. Rich Rosy, vice president at Ingram Library Services, noted in 2011 that he was beginning to see collections policies that stated a general preference for electronic formats. ${ }^{2}$ Reasons for choosing electronic formats include diminishing space on library shelves as well as the convenience that electronic materials offer to both local and distance students. Policies that give priority to e-book purchases are referred to as e-preferred (that is, electronic format preferred), in contrast to e-only policies, which state that a library will purchase only materials in electronic format. An e-preferred policy indicates the library will still accept physical copies when an e-book is unavailable or when it is significantly delayed relative to the print edition.

The delay between a print book's publication and the release of its electronic counterpart can cause a dilemma for libraries. Though e-books benefit remote users, multiple simultaneous users, or people looking for books at times the library is closed, waiting to make a purchase until a book is available in electronic format can mean that the content of a particular book is not available to any library patrons until months after the book was originally released. Purchasing a print copy at the time of publication usually means acquiring the desired content earlier; but, since most libraries cannot afford to regularly buy the same books in two different formats, buying print means forgoing the benefits of e-books. If the delay between print and electronic publication for a particular book is brief, waiting for the e-book may be a good decision. If libraries

Karen Kohn is Collections Analysis Librarian in Paley Library at Temple University; e-mail:karen.kohn@ temple.edu. (C)2018 Karen Kohn, Attribution-NonCommercial (http://creativecommons.org/licenses/by$n c / 4.0 /)$ CC BY-NC. 
knew the delay would be long, they might choose to buy the print version in the interest of gaining access to the content in a timely manner. Since libraries do not usually know how long the delay will be, there is a danger of waiting several months for an e-book only to end up buying the less-preferred format after all. Waiting to buy a print book also carries the risk that the print book could go out of stock.

Since publication schedules vary, even between books by the same publisher, knowing how long to wait for an e-book is difficult. A common practice is to decide on a standard amount of time that a library is willing to wait to see if an e-book becomes available. Libraries that use approval plans set the length of their wait period for each subject profile. The length of the wait period can be decided based on overall publication patterns, the strength of the library's preference for e-books, and the value the librarians or users place on acquiring books promptly after publication. However, there is very little literature on publication patterns to help librarians select the length of their wait period in an evidence-based way. With the goal of providing data to help librarians make informed decisions, this paper presents and analyzes recent e-book publication patterns by subject and asks, is there an optimal wait period that balances the desire to get books soon after publication with the desire to get as many as possible electronically?

\section{Literature Review}

In the last six years, acquisition of electronic formats has become a significant part of academic libraries' collection development. An Ithaka survey in 2010 found that library directors expected their budgets to shift away from printed books toward e-books, ${ }^{3}$ and the Charleston conference that year reflected a similar sentiment. Herman ${ }^{4}$ noted a change in tone at that conference, with participants sounding more serious about designating parts of their budgets to e-book purchases. Library Journal found a 41 percent increase from 2011 to 2012 in the number of e-books carried by academic libraries. ${ }^{5}$ By 2014, public and academic libraries were devoting 11 percent of their materials budgets to e-books. ${ }^{6}$ A recent survey of academic libraries by ProQuest found 46 percent of libraries spending more than a fifth of their book budgets on e-books. The same survey showed 41 percent of respondents having e-preferred collection policies. ${ }^{7}$

There are several reasons for the rise in e-book purchasing. Users' expectations for remote access have increased, ${ }^{8}$ influenced by the growth of distance education and greater availability of information online. Another major issue is space constraints. Libraries are not only running out of room to house printed materials, ${ }^{9}$ but there have been calls in recent years for prioritizing student spaces over collections, including offering study rooms, collaborative work spaces, or support services such as a writing center within the library. ${ }^{10}$ Shifting new book purchases to electronic formats addresses both of these needs. In addition, an appealing feature of e-books is that they can be purchased through Demand-Driven Acquisitions (DDA) with no delay between the user's request and gaining access to the book. DDA in any format is a cost-saving option, as it allows the library to only pay for books that it knows will be used. When this purchasing strategy is used for print materials, in contrast, there is a delay between the patron's request and the library acquiring the item. DDA is more seamless for e-books, as purchases can be triggered automatically when a user clicks a link in the library catalog. As DDA grows in appeal as a cost-saving strategy, the relative ease of implementing it for e-books compared to print has encouraged some libraries to shift their book purchasing to electronic form. ${ }^{11}$

Libraries have reasons for not switching their book purchasing entirely to e-books, however. One hesitation is that users sometimes say they don't especially like e-books. Even patrons who use e-books for quick lookup often prefer print books for in-depth reading, ${ }^{12}$ and patrons sometimes have difficulty navigating the interfaces of e-book 
platforms. ${ }^{13}$ Another deterrent to purchasing e-books has been that electronic versions simply do not exist for all monographs. A study at Menlo College in 2011-2012 found that, after four months, only 50 percent of the books the library had purchased in the previous quarter were available as e-books through any major aggregator. ${ }^{14}$ In 2013, Jennifer $\mathrm{O}$. Yao researched the availability of art books in electronic form across two major aggregators and fifty-four publishers' websites. Of the fifty-four publishers she researched, only twelve offered frontlist e-books through the library's main book vendor. Nineteen provided no e-books at all. ${ }^{15}$

Even when publishers do offer e-books, these are sometimes released well after the print version. A study conducted in 2013 at RMIT University Library in Australia asked whether that library's print holdings could theoretically be replaced with e-books. The researchers found that more than 60 percent of books three to seven years old were available as e-books, while only 41.67 percent of more recent books existed in e-book form. ${ }^{16}$ Delays in publication often leave librarians to "choose between buying the print version upon publication or making their patrons wait, often for months, before the e-book appears." ${ }^{17}$ A survey of ARL libraries in 2009 concluded that its participants would be buying more e-books if they were available at the same time as print. ${ }^{18}$

The issue of publication delay has improved, but not disappeared, since the ARL survey was done. Wiersma's study of publication patterns in the four years from 2008 to 2011 found that the average delay was decreasing. ${ }^{19}$ In 2011, Anne-Marie Breaux of YBP Library Services (formerly Yankee Book Peddler) was quoted as saying, "When we first started profiling ebooks simultaneous with print a few years ago, we were seeing about $10-12 \%$ offered both formats, and today that is about $20-25 \%$ of new titles each week." ${ }^{20}$ Just two years later, a 2013 study of YBP's catalog found 40 percent of the new books they sell were available simultaneously in print and electronically. ${ }^{21}$

For books that are not released simultaneously in both formats, deciding how long to wait for a possible e-book remains an issue for librarians. Wiersma ${ }^{22}$ cautions that waiting too long before purchasing a print book may result in the item being out of stock and unavailable for purchase. Ordering print too soon has a risk as well. Once a library has bought the print, it is unlikely to buy the e-book when it comes out later, unless there is money to spend on duplicate content. ${ }^{23}$ The library is then left with a book in its less preferred format. Michael Levine-Clark's 2007 statement is still true today: "Though we do not need publishers to make all titles available in eBook form, we do need to understand the patterns they are using to make these decisions in order to write eBook coverage into our approval plan." ${ }^{24}$

Counterintuitively, the best way to understand these patterns is not necessarily to ask the publishers. One reason for this is that the answers publishers give when asked about simultaneous publication tend to differ from what librarians observe. Tony Sanfilippo ${ }^{25}$ of Ohio State University Press says that, at his organization, simultaneous publication is the default unless there is an obstacle, such as a licensing restriction on some of the content in the book. Librarians' perception, on the other hand, is commonly that publishers deliberately delay e-book publications to ensure they sell copies in print. ${ }^{26}$ Part of this discrepancy might be that publishers use language that is not always clear to librarians. Zeoli ${ }^{27}$ notes that publishers sometimes say that they offer 100 percent of their books simultaneously as print and e-books, when in fact they mean that if they are able to publish a book electronically, they do so simultaneously to the print. Some books cannot be produced as e-books, for reasons explained below.

Another reason publishers might not have a simple answer regarding their standard delay for e-books is that the delay can vary by book. In order for a publisher to release a book electronically, not only does the author's contract need to explicitly give this permission, but any third-party permissions for image files also need to say that the 
images can be used in an e-book. ${ }^{28}$ Sometimes the rights-holders for image files grant limited permissions that turn out to prevent a book from being released as an e-book at all. An example would be if the rights-holder wants to restrict the number of times an image can be viewed or make it only available for a set number of years. ${ }^{29}$ In other cases, the images produce a file size that is too large for publishers to use..$^{30}$ Because of the variations in situations for individual books, it is not possible for publishers to have a universal policy for how soon they release e-books. Even when simultaneous publishing is the default, there will be books whose circumstances deviate from that default.

Many publishers offer their e-books as packages, which could include all books published in a particular year, all books in a series regardless of publication year, or a collection of books within a subject area. Because e-book packages include books with different publication dates, delay is not as relevant when considering the purchase of a package. E-book packages are more typically differentiated by whether they include frontlist titles or backlist. Looking closely at the time elapsed from print publication to e-book publication is only possible or relevant when a library is purchasing individual titles. ProQuest's 2016 survey of academic libraries found that 76 percent were selecting e-books title-by-title, ${ }^{31}$ so information that can be used when purchasing individual e-books is relevant to many libraries.

While smaller libraries can treat each book as an individual case and decide if the e-book is worth waiting for, in academic libraries the "most accepted and widely used means of acquiring monographs" 32 is the approval plan. The two major companies offering academic approval plans in the United States are ProQuest Coutts and YBP Library Services. ${ }^{33}$ Approval plans operate by allowing a library to create a profile, which is a list of criteria for books the library will accept. The criteria begin with call number ranges, but a profile can also be limited to certain publishers, languages, or readership levels and can have a price cap as well. The vendor then takes on the responsibility of identifying newly published books that match the library's profile. Traditionally, the vendor ships the books, and the library has the option of returning items they don't want. ${ }^{34}$

Coutts has allowed e-books to be purchased via approval plan since 2007, and YBP at that point offered e-books from netLibrary and was working on integrating ebrary and EBL (Ebook Library). ${ }^{35}$ The way Coutts' approval plans currently work is that a library can set up an e-preferred profile, which includes subjects and publishers that the library would prefer to receive as e-books. The plan can either specify that e-books matching the profile be added to the library's collection in Ebook Central (ProQuest's ebook platform) or that records be provided for Demand-Driven Acquisitions (DDA). The library also decides how long it is willing to wait for an e-book to become available. When a print book is reviewed by Coutts, if it matches the library's profile it will be marked as On Hold for Alternate Editions. If an e-book becomes available during the on-hold period, the library receives either the e-book or a DDA record, according to the settings of the profile. If the wait period expires and still no e-book has become available, Coutts will ship the print. If a librarian is looking for a specific book and sees it marked On Hold for Alternate Editions, he or she can override the e-preferred policy and elect to have the print shipped right away.

There are several factors involved in deciding how to set up an e-preferred profile. One consideration is which publishers to include. A library may want to exclude publishers that are known to have long delays between print and e-book release dates. ${ }^{36}$ These publishers could then be listed on a separate profile for print books. A profile for Demand-Driven Acquisitions of e-books would only include publishers who participate in the aggregator's DDA program. Another feature of an e-preferred profile is the length of the wait period, which should balance the value of getting books soon 
after their publication with the strength of the library's preference for the electronic format. The wait period can differ by subject, depending on preferences of users in that discipline. Wiersma ${ }^{37}$ explains how, at the University of Colorado Boulder, the science librarians had such a strong preference for e-books that they set a wait period of 180 days, while humanities librarians chose a much shorter wait period. An important piece of information in deciding the wait period, of course, would be information about typical lag times between print and electronic publication.

\section{Background}

In an effort to provide such information, this paper analyzes books that matched the approval plan for Temple University Libraries. The main library, Paley, serves more than 28,000 undergraduates, 9,000 graduate students, and more than 2,000 full-time faculty members. The university's library system includes a Law Library and Health Sciences Library, whose book ordering was not included in this study.

Paley Library initiated an e-preferred approval plan with Coutts in July 2014. The beginnings of a preference for electronic formats can be seen in the library's 2009-2012 Strategic Plan, which notes that "Collection of monographs will remain robust; however innovations in the technology and digital rights management of e-books could begin to make them an attractive alternative." ${ }^{\prime 38}$ The Strategic Plan also states that storage space is a concern. Although the document does not explicitly mention e-books as a solution for space issues, awareness of this concern has influenced the shift toward electronic resources as well.

Paley Library has received a significant number of e-book records since adopting the e-preferred profile in 2014. However, in that time there have been a few thousand books so far that did not become available as e-books within the thirty-day on-hold period and were therefore shipped in print. This led to a delay in receiving print books that concerned some librarians. Shortening the wait period would mean that the print books Paley Library receives would arrive sooner after publication, but it also would probably mean receiving more hard copies of books, which is not the library's general preference. The question arose whether it would be possible to shorten the on-hold period in such a way that the cost of receiving more print would be outweighed by the benefit of getting books faster. This required having an educated guess of how many more print books would be received if the wait period were shortened. The formulation of such an educated guess was the goal of this study.

\section{Research Questions}

To date, there is only one study in the library literature comparing electronic and print book publication dates. The study, by Gabrielle Wiersma, ${ }^{39}$ calculated the average number of days between publication of a print book and its electronic counterpart. The current paper uses a different methodology, looking instead at the distribution of e-book release dates to show how many are published simultaneously to the print, how many come out one day later, and so forth. The research questions addressed by this study are:

1. Has simultaneity of electronic and print publishing become more common than what has been reported in the past?

2. What does the distribution of e-book publication dates look like? Might librarians expect an e-book to be released at any time after its print counterpart, or are certain length delays more common than others?

3. How does the distribution differ if the analysis is based on the dates that the vendor profiles the books (in other words, decides if they match the library's approval profile so they can be sent to the library) rather than publication dates? 
4. What is the optimal wait period for Temple University Libraries' current epreferred plan with Coutts?

The answers to these questions can contribute to librarians' overall knowledge of how the publishing industry is changing with regard to e-books and can help librarians make informed decisions about how long to set the wait periods on their e-preferred approval plans. Libraries without approval plans can also use the information shared in this study to decide when to wait for electronic versions of books rather than buying the print as soon as it is published.

In looking for answers to these questions, the author reviewed the approval plan history for Temple University over a period of seventeen months. Comparing e-book and print publication dates revealed the critical point at which a longer wait period is not likely to yield enough e-books to justify itself. Table 3 below provides critical points for each subject for which Temple has an approval profile. This information can help other libraries make decisions, as well as providing a snapshot to help track how publication patterns are changing over time.

\section{Methodology}

This study analyzed records from all the books that matched Temple University's epreferred approval plan from July 2014 to November 2015. The e-preferred approval plan profiles include only publishers that offer Demand-Driven Acquisitions via the library's preferred e-book platform. At the time of this study, Paley Library was using MyiLibrary as its main aggregator for Demand-Driven Acquisitions (DDA). MyiLibrary has since been subsumed into Ebook Central, also provided by ProQuest, which offers a similar DDA program. Because the plan is actually "DDA-preferred," ${ }^{40}$ publishers that offer ebooks only as traditional purchases are excluded. Temple also uses print approval plans for publishers that do not participate in DDA.

E-books that match the e-preferred profile are made available to Temple University Libraries as candidates for DDA. If a book matches the e-preferred profile but is not yet available as an e-book, Coutts' ordering platform, OASIS, will show the title as On Hold for Alternate Editions. The on-hold period was initially set at thirty days. Titles that are not available electronically after thirty days are shipped in print. The data for this study included all books that matched the e-preferred profile, both those that were made available in MyiLibrary and those that Paley Library received in print.

There were four stages of data collection:

1. create a list of books received in print

2. determine if and when these books had been published as e-books in MyiLibrary

3. create a list of books received as DDA titles from the e-preferred plan

4. gather publication dates of these books' print counterparts

The data also included the date the books were marked as "Selection Cycle Complete" in both print and electronic formats. The designation of "Selection Cycle Complete" means that Coutts had finished describing a given book and determining whether it matched one of the library's profiles. Coutts refers to this process as profiling or treating the book. All data were collected using OASIS, Coutts' ordering platform, and exported to Excel.

Gathering e-book information on the titles received in print involved copying ISBNs from the Excel file and pasting them as a batch into OASIS. For each record, the results screen shows whether there is an e-book edition. There were 2,907 titles shipped in print that matched Temple University's e-preferred profiles from the week ending July 4,2014 , to the week ending November 27, 2015. Of these, 631 had become available as e-books in MyiLibrary as of March 21, 2016, the date the data collection finished. Only MyiLibrary editions were counted, even though OASIS shows availability in EBSCO 
as well, because Temple does not have a DDA plan with EBSCO. After removing from the dataset some books whose records had a note of "will not be treated" (that is, they never went through the 30-day on-hold period), 2,891 books that the library had received in print remained in the dataset.

The next step focused on books that were sent to the library as MARC records for DDA. A representative from Coutts sent a report listing the 12,000 titles that were made available in Temple's DDA collection between July 2014 and November 2015. These were also searched in OASIS, and a parallel list was developed showing the paperback and cloth editions of the titles. After removing titles that had no corresponding print edition or ones that were no longer listed in OASIS, 10,152 titles were left. The two lists together provided a total of 13,043 books for analysis.

The two datasets were compiled into a master spreadsheet, which included publication date and "Selection Cycle Complete" date for cloth, paperback, and e-book editions. The chart noted which format had been sent and which subject profile it had matched. The spreadsheet also included two calculated fields: the publication delay and the selection cycle delay. Publication delay was calculated as the date of e-book publication minus the date of either paperback or cloth publication, whichever was earlier. The selection cycle delay was calculated similarly. A negative delay means the e-book was available first.

\section{Results}

The analysis was targeted toward answering the four research questions.

Question 1. What percentage of e-books are published simultaneously to print, or earlier? Has simultaneity of electronic and print publishing become more common now than what was described in earlier published articles?

The data shown in table 1 provide an answer to question 1, which asks how often e-books were published simultaneously to or earlier than print. The data showed differences between disciplines, with Computer Science standing out as having the highest degrees of simultaneity and Linguistics and Spain \& Portugal having the lowest. Overall, 35.01 percent of all the books on Temple University's e-preferred profile are published simultaneously in both formats. The second part of the question concerned how the results of this study compared to statistics mentioned in previously published articles. The number of simultaneous publications shown in table 1 is a bit lower than the 2013 finding that 40 percent of the new books YBP sold had simultaneous publication. ${ }^{41}$ This is surprising, given that the 40 percent figure represented a large increase from what YBP had been seeing two years earlier, but the difference may be that the data in the current study only consider what is available in one e-book aggregator. Several of the titles in this study that were not available on MyiLibrary were available as EBSCO e-books, so availability would have been higher if both platforms were included.

To see how Coutts' profiling process might be affecting when e-books become available, further analysis considered whether e-books that were published prior to the print were also profiled earlier. Out of the 13,043 books in the dataset, 4,222 of them had e-books that came out before the print. Yet only 1,196 of these e-books were profiled before the print. Additionally, 1,590 e-books were published after the print yet profiled first.

There could be a few different reasons for these discrepancies. Sometimes the e-book comes out before the print but is not added to MyiLibrary until later, which would delay the Selection Cycle Complete date. Other times, the e-book goes through the selection cycle in the United Kingdom before it is actually available in the United States, leading to an early Selection Cycle Complete date. Since the calculation of how long to wait for an e-book is based on the Selection Cycle Complete date rather than 


\begin{tabular}{|c|c|c|}
\hline \multicolumn{3}{|c|}{$\begin{array}{c}\text { TABLE } 1 \\
\text { Percentage of Print Books whose Electronic Counterparts Were Published } \\
\text { Simultaneously or Before Print }\end{array}$} \\
\hline Subject Profile & $\begin{array}{c}\text { Percentage } \\
\text { of Books }\end{array}$ & $\begin{array}{c}\text { Number of Simultaneous } \\
\text { Books / Total Books in Dataset }\end{array}$ \\
\hline African-American Studies & $37.05 \%$ & $133 / 359$ \\
\hline Anthropology & $34.35 \%$ & $79 / 230$ \\
\hline Art \& Architecture & $28.80 \%$ & $106 / 368$ \\
\hline Business & $42.78 \%$ & $468 / 1094$ \\
\hline Classics & $30.77 \%$ & $44 / 143$ \\
\hline Communication Disorders & $44.12 \%$ & $15 / 34$ \\
\hline Communication and Media Studies & $37.29 \%$ & $157 / 421$ \\
\hline Community and Regional Planning & $41.31 \%$ & $126 / 305$ \\
\hline Computer Science & $48.48 \%$ & $48 / 99$ \\
\hline Economics & $35.54 \%$ & $134 / 377$ \\
\hline Education & $41.08 \%$ & $364 / 886$ \\
\hline Engineering & $35.20 \%$ & $151 / 429$ \\
\hline English Language \& Literature & $28.29 \%$ & $290 / 1025$ \\
\hline Film Studies & $31.58 \%$ & $84 / 266$ \\
\hline Geography \& Urban Studies & $37.50 \%$ & $48 / 128$ \\
\hline German Language \& Literature & $32.50 \%$ & $13 / 40$ \\
\hline Health Education & $32.84 \%$ & $44 / 134$ \\
\hline History & $34.76 \%$ & $513 / 1476$ \\
\hline Horticulture & $40.70 \%$ & $35 / 86$ \\
\hline Latin American Studies & $27.54 \%$ & $19 / 69$ \\
\hline Leisure and Tourism & $43.27 \%$ & $74 / 171$ \\
\hline Library Science & $26.89 \%$ & $32 / 119$ \\
\hline Linguistics & $18.31 \%$ & $13 / 71$ \\
\hline Music & $32.51 \%$ & $79 / 243$ \\
\hline Public Health & $32.43 \%$ & $144 / 444$ \\
\hline Political Science & $32.01 \%$ & $250 / 781$ \\
\hline Psychology & $39.56 \%$ & $216 / 546$ \\
\hline Religion & $31.72 \%$ & $236 / 744$ \\
\hline French \& Italian Language and Literature & $34.92 \%$ & $22 / 63$ \\
\hline Science & $34.34 \%$ & $216 / 629$ \\
\hline Sociology & $31.39 \%$ & $178 / 567$ \\
\hline Spain \& Portugal & $20.51 \%$ & $8 / 39$ \\
\hline Social Work & $39.47 \%$ & $75 / 190$ \\
\hline Theater & $28.71 \%$ & $58 / 202$ \\
\hline
\end{tabular}


publication dates, analysis from this point on focused on the dates that books were marked Selection Cycle Complete. Some information on publication is included to help libraries that might not be using an approval plan.

Question 2. What does the distribution of e-book publication dates look like?

Question 3. How does the distribution differ if the analysis is based on the dates that Coutts profiles the books (Selection Cycle Complete date) rather than publication dates?

Since the majority of e-books are still not being released at the same time as their print counterparts, it is useful for libraries to understand whether there is a pattern in the publication delays. Question 2 asks whether certain lengths of delay are more common than others, and, if so, what the pattern looks like. The first step in answering this question was to count how many books on each approval profile had no delay, a one-day delay, and so forth. A graph based on these counts is shown in figure 1. The figure shows what percentage of books matching Temple University's e-preferred profiles would the libraries theoretically receive as e-books if the wait period were zero days, one day, and so forth. The calculations used to create figure 1 are based on the full set of 13,043 books that matched Temple's approval profiles. This figure ends at day 115 because all of the books in the dataset were at least 115 days old at the time the data was collected.

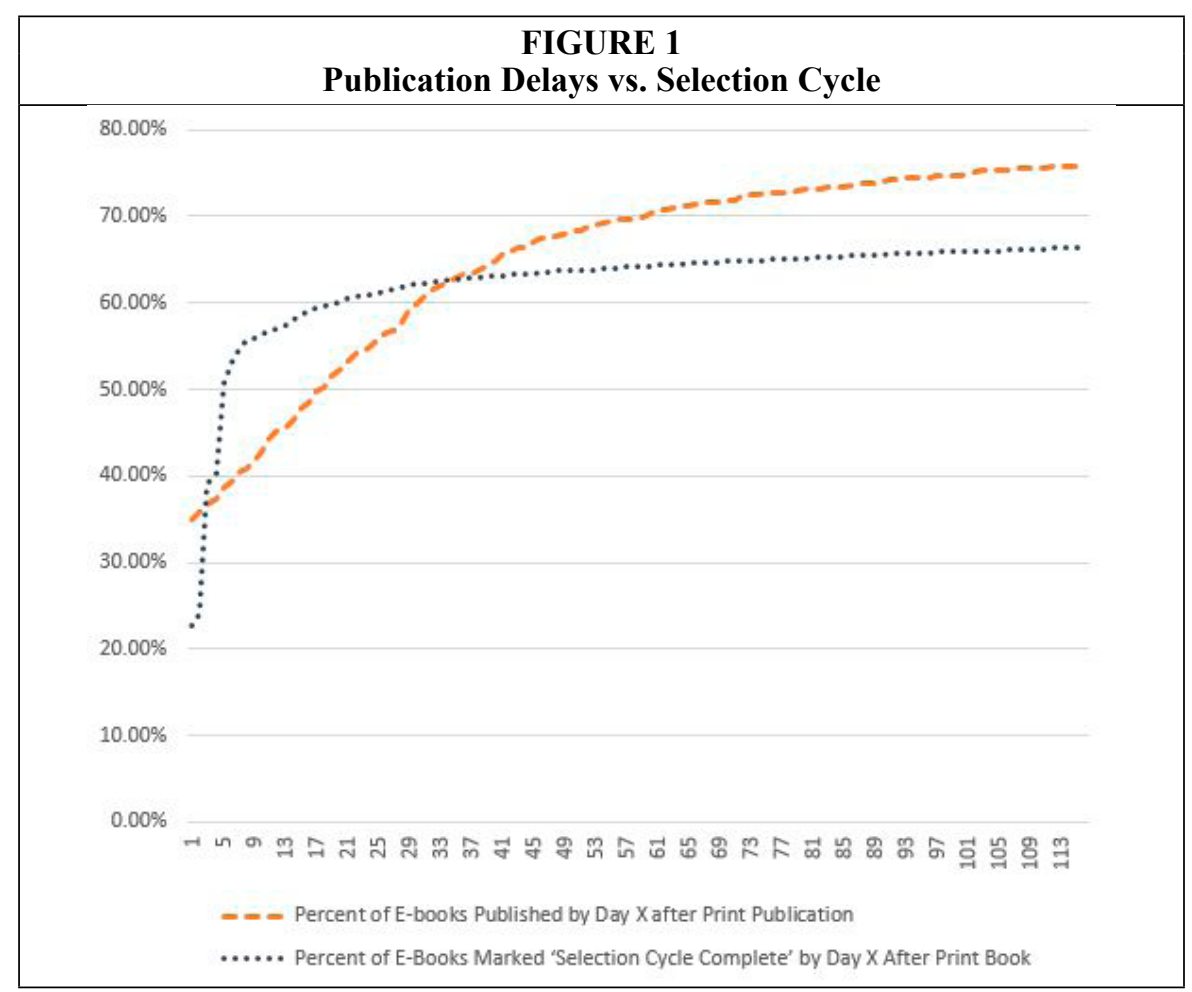

According to figure 1, theoretically if Temple University Libraries were to only purchase e-books that were published the same day as the print (day zero, dashed line), 35.01 percent of books on the e-preferred profile would be delivered as e-books. In actuality, Coutts starts the on-hold period the day a book is marked Selection Cycle Complete, so an on-hold period of zero would mean that Coutts completed the pro- 
filing process for both on the same day, regardless of when the book was published. Because Coutts' decision to ship a book in print instead of waiting for the e-book is dependent on their Selection Cycle process, the library's decisions should also be based on Coutts' profiling process, rather than on publication dates. The data on publication delays is useful for understanding how the publishing world is changing, but the line representing Coutts' selection cycle is more relevant for this particular library's decision of how to configure its approval plan.

The dotted line in the graph, which is based on the date Coutts marks books Selection Cycle Complete, shows that a zero-day wait period would mean that only 22.64 percent of the books on Temple University's e-preferred profiles would be delivered as e-books. Sometimes e-books do not finish their profiling process until Coutts has

\begin{tabular}{|l|l|l|}
\hline \multicolumn{2}{|c|}{$\begin{array}{c}\text { TABLE 2 } \\
\text { Hypothetical Scenarios }\end{array}$} \\
\hline \multicolumn{2}{|c|}{ Example 1. E-book is published four days before print but profiled one day after print. } \\
\hline Day 0 (Publication) & \multicolumn{2}{|l|}{ E-book is published. } \\
\hline Day 4 (Publication) & Print Book is published. & \\
\hline $\begin{array}{l}\text { Day 14 (Publication)/Day 0 } \\
\text { (Selection Cycle Complete) }\end{array}$ & $\begin{array}{l}\text { Print Book is marked } \\
\text { Selection Cycle Complete. }\end{array}$ & $\begin{array}{l}\text { Information from print book } \\
\text { record copied over to e-book } \\
\text { record. E-book is marked } \\
\text { Selection Cycle Complete. }\end{array}$ \\
\hline $\begin{array}{l}\text { Day 15 (Publication)/Day 1 } \\
\text { (Selection Cycle Complete) }\end{array}$ & & \\
\hline
\end{tabular}

Example 2. E-book is published ten days after print but profiled one day after print.

\begin{tabular}{|l|l|l|}
\hline Day 0 (Publication) & Print Book is published. & \\
\hline Day 10 (Publication) & & E-book is published. \\
\hline $\begin{array}{l}\text { Day 14 (Publication)/Day 0 } \\
\text { (Selection Cycle Complete) }\end{array}$ & $\begin{array}{l}\text { Print Book is marked } \\
\text { Selection Cycle Complete. }\end{array}$ & \\
\hline $\begin{array}{l}\text { Day 15 (Publication)/Day 1 } \\
\text { (Selection Cycle Complete) }\end{array}$ & & $\begin{array}{l}\text { Information from print book } \\
\text { record copied over to e-book } \\
\text { record. E-book is marked } \\
\text { Selection Cycle Complete. }\end{array}$ \\
\hline
\end{tabular}

Example 3. E-book is published after the On Hold period has ended. It is not automatically made available to the library, as the print has already been shipped.

\begin{tabular}{|l|l|l|}
\hline Day 0 (Publication) & Print Book is published. & \\
\hline Day 7 (Publication) & $\begin{array}{l}\text { Print Book is marked } \\
\text { Selection Cycle Complete. } \\
\text { Coutts places it On Hold } \\
\text { for Alternate Editions. }\end{array}$ & \\
\hline $\begin{array}{l}\text { Day 37 (Publication)/ } \\
\text { Day 30 (Selection Cycle } \\
\text { Complete) }\end{array}$ & $\begin{array}{l}\text { On Hold period expires. } \\
\text { Print is shipped to library, } \\
\text { as no e-book has become } \\
\text { available. }\end{array}$ & \\
\hline $\begin{array}{l}\text { Day 45 (Publication)/ } \\
\text { Day 38 (Selection Cycle } \\
\text { Complete) }\end{array}$ & & E-book is published. \\
\hline
\end{tabular}


the print in hand, so their Selection Cycle Complete date comes just after the print. Within two days after print books are marked Selection Cycle Complete, though, 41.36 percent of their electronic counterparts have also gone through the selection cycle. As shown by the dotted line in figure 1, it would only take a four-day wait from the time each print book completed the selection cycle before half of these books were also available electronically and had been profiled. Some hypothetical example scenarios are shown in table 2.

Prior to this research, Temple University's on-hold period was thirty days, which means the library should have gotten 62.27 percent of the books that matched its approval profiles as e-books. In fact, somewhat more books were delivered electronically than figure 1 predicts. Because the data are based on delays from the print book's availability to the e-book, they do not include e-books that do not have a print counterpart available. Temple actually received some e-books that were not counted in this dataset, either because they had no print edition or because the print edition had not yet been marked Selection Cycle Complete at the time of the data collection. A more accurate way to read the figure 1, then, would be to say that the library should receive at least the percentage of books indicated.

These findings seem to show an improvement since the Menlo College study in 2011-2012. That study found 50 percent of books available as e-books four months after the print publication. ${ }^{42}$ The data included here show that 115 days (just shy of four months) after publication, 75.80 percent of Paley Library's print purchases were available as e-books. It should be noted, though, that these data only include publishers that were known to offer DDA in MyiLibrary, and that the number of books available overall could be higher (if the data included additional e-book aggregators, publisher platforms, and non-DDA e-books) or lower (if the data included publishers

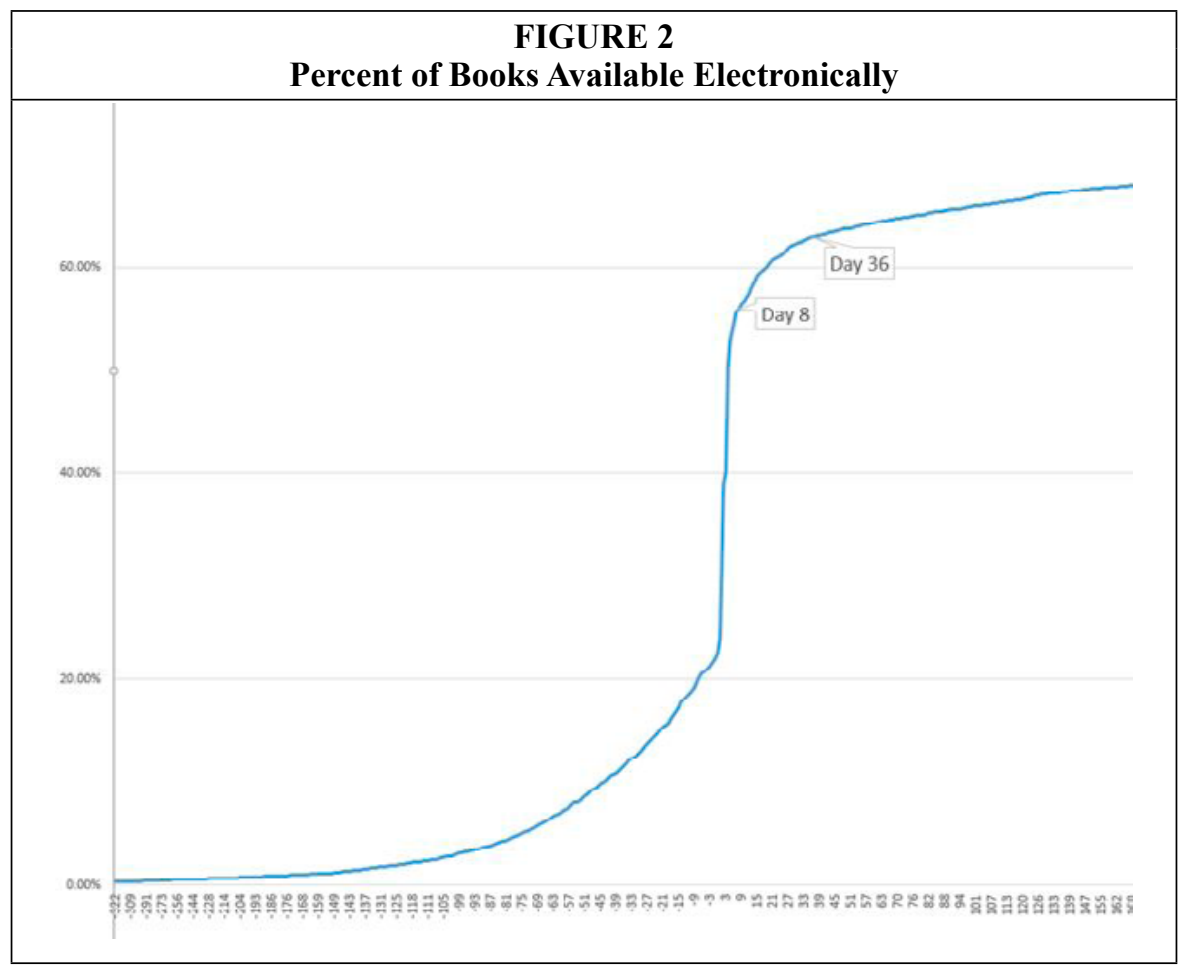


that don't regularly offer e-books). It is probable that more books published in recent years are available as e-books than were available in 2012, but it is hard to say exactly how many more.

Question 4. What is the optimal on-hold period for Temple University Libraries' current e-preferred plan with Coutts?

Figure 1 shows that every day a library waits could mean that additional books become available as e-books. However, the graph reveals that there is a point at which waiting is no longer worthwhile, at least for subjects on which the library is willing to accept print. This point provides an answer to question 4, which asks when the optimal wait period would be for Temple University's e-preferred approval plan. To help identify the point at which waiting for an e-book becomes no longer desirable, figure 2 presents an enlarged version of the dotted line in figure 1 . The line shows the percent of all books on the e-preferred plan that the library would expect to receive electronically, given various on-hold periods. The graph is based on selection cycle delays, since the Selection Cycle Complete date is when Coutts' on-hold period starts.

From this image, it is clear that, within the early days of a book's publication, a short wait would allow a library to purchase many more e-books. The line curves sharply upward as the number of e-books goes up with each day's wait. After seven days, however, the line starts to level off. On day 7, waiting an additional day would allow a library to receive 1.12 percentage points more of its monographs as e-books, while on the eighth day the library only receives 0.28 percentage points more. The percentage of books received as e-books given a seven-day wait is 55.70 percent, while an eightday wait would yield 55.98 percent, an increase of 0.28 percentage points. A similar shift happens on day 36. After several days during which waiting another day would yield 0.1 percentage points more e-books, lengthening the wait period from thirty-five to thirty-six days returns only .05 percentage points more books. The percentage of books received as e-books given a 35-day wait is 62.91 percent, while a 36-day wait would yield 62.96 percent, or an increase of .05 percentage points.

The curve in figure 2 never becomes flat. It continues to slope upward as it moves to the right, showing that waiting longer will always result in more e-books becoming available. At some point, though, the increase in e-books for each day's wait becomes very small. Because the graph never becomes flat and also does not have a sharp dropoff, there is not a clear point at which it can be said definitively that libraries should stop waiting for an e-book to become available. Anywhere between the two points where the curve shifts its course could be a reasonable wait period. Whether a given library chooses a higher or lower number will depend on how strongly the library favors e-books and the value it places on receiving books while they are still relatively recent publications.

Since Coutts allows a different wait period to be set for each subject profile, it could also be useful to plot a curve for each profile and to identify where that curve shifts its course. Due to space considerations, the graphs for each of Temple University Libraries' approval profiles are not included here. A summary of findings is provided in table 3, which is based on Selection Cycle Complete dates from Coutts. A library could choose to use either the upper or lower bound recommended in the table depending on the preferences of each discipline. Recall that, at the University of Colorado Boulder, the on-hold periods varied significantly by discipline, with sciences preferring e-books so strongly that they were willing to wait 180 days from the time a print book was published in hopes of receiving the book electronically. ${ }^{43}$ Though none of the subjects in table 3 have a suggested wait time nearly that long, it is possible in theory that an approval profile in Business could set its on-hold period at 49 days, whereas many other subjects might choose to wait only a week. 


\begin{tabular}{|c|c|c|}
\hline \multicolumn{3}{|c|}{$\begin{array}{c}\text { TABLE } 3 \\
\text { Recommendations for On Hold Periods, In Days }\end{array}$} \\
\hline Profile & $\begin{array}{l}\text { Lower Bound } \\
\text { (when increase in } \\
\text { e-book receipts } \\
\text { drops consistently } \\
\text { below } 1 \% \text { a day) }\end{array}$ & $\begin{array}{c}\text { Upper Bound } \\
\text { (first day on which } \\
\text { no more e-books will } \\
\text { be received for three } \\
\text { or more days) }\end{array}$ \\
\hline African-American Studies & 7 & 32 \\
\hline Anthropology & 5 & 24 \\
\hline Art \& Architecture & 6 & 28 \\
\hline Business & 8 & 49 \\
\hline Classics & 8 & 13 \\
\hline Communication Disorders & 3 & 8 \\
\hline Communication and Media Studies & 7 & 20 \\
\hline Community and Regional Planning & 6 & 10 \\
\hline Computer Science & 8 & 8 \\
\hline Economics & 7 & 29 \\
\hline Education & 8 & 29 \\
\hline Engineering & 8 & 28 \\
\hline English Language \& Literature & 8 & 48 \\
\hline Film Studies & 8 & 17 \\
\hline Geography \& Urban Studies & 6 & 8 \\
\hline German Language \& Literature & 5 & 5 \\
\hline Health Education & 8 & 9 \\
\hline History & 8 & 38 \\
\hline Horticulture & 6 & 8 \\
\hline Latin American Studies & 8 & 8 \\
\hline Leisure and Tourism & 6 & 20 \\
\hline Library Science & 7 & 20 \\
\hline Linguistics & 5 & 8 \\
\hline Music & 7 & 17 \\
\hline Public Health & 7 & 8 \\
\hline Political Science & 7 & 29 \\
\hline Psychology & 7 & 28 \\
\hline Religion & 7 & 36 \\
\hline French-Italian Language and Literature & 8 & 5 \\
\hline Science & 7 & 27 \\
\hline Sociology & 7 & 28 \\
\hline Spain \& Portugal & 6 & 6 \\
\hline
\end{tabular}




\begin{tabular}{|l|c|c|}
\hline \multicolumn{3}{|c|}{ TABLE 3 } \\
\hline Recommendations for On Hold Periods, In Days \\
\hline Profile & $\begin{array}{c}\text { Lower Bound } \\
\text { (when increase in } \\
\text { e-book receipts } \\
\text { drops consistently } \\
\text { below 1\% a day) }\end{array}$ & $\begin{array}{c}\text { Upper Bound } \\
\text { (first day on which } \\
\text { no more e-books will } \\
\text { be received for three } \\
\text { or more days) }\end{array}$ \\
\hline Social Work & 10 & 21 \\
\hline Theater & 7 & 12 \\
\hline Women's Studies & 6 & 16 \\
\hline Total & 7 & 36 \\
\hline
\end{tabular}

If publication patterns for each of Temple University Libraries' approval profiles were graphed separately, the graphs would follow a similar shape to figure 2, climbing upward and then turning a corner. For each profile in table 3, the lower recommendation is the point at which the percentage of books received electronically would increase by less than 1 percent with each additional day's wait, which is generally where the graphs turn the corner. The upper recommendation point is where waiting one additional day would yield no additional e-books (an increase of zero percentage points). To ensure that the upper number reflected where the graph actually leveled out rather than one anomalous day of no new e-books, the upper bound is where the increase drops to zero and stays there for three or more days. As stated earlier, the graphs do not completely level out, as the percentage of books available electronically continues to grow over the entire time period studied. However, if there are three days in a row of no gain in e-books, then a day or two of some more becoming available, followed by three more days of none, it is unlikely the library will decide that the wait time is worth the gain. The upper recommendation was calculated differently for the dataset as a whole than it was for each separate profile, because the increase in e-book availability never drops to zero. The upper recommendation for Temple's e-preferred profile overall was decided based on where the graph in figure 2 started to level out: day 36 .

\section{Discussion}

The data provided here reveal that it is still difficult to predict exactly when a given book is going to become available electronically. The number of e-books published simultaneously to print appears to be no greater than it was three years ago, and lag times vary significantly. Though half of the books on Temple University's profile were released electronically within seventeen days of print publication, more e-books became available with each additional day. There is no clear point when a librarian can conclude that, if the e-book has not become available yet, it will never be available. Yet there are some points at which a librarian could decide e-books were no longer worth the wait. These points would be the two places on the graph where the percentage of books available electronically starts to increase less rapidly and then where it nearly levels off. Other libraries can use the data provided here to make their own decisions of how long their standard wait periods should be.

At Temple University, these data allowed Paley Library to significantly shorten its on-hold period, from thirty days to fifteen days across the board. If this wait period had been in effect in 2014-2015, the library would have received 468 more print books. Meanwhile, the 2,891 books from e-preferred profiles that the library did receive in 
print during that time period would have arrived fifteen days sooner. Based on these data, shortening the on-hold period seemed to be a worthwhile tradeoff, and this change has been made.

Additional analysis at the publisher level would have been useful. Wiersma ${ }^{44}$ provides numbers on the average publication delays for various trade publishers and university presses. Libraries might choose to remove from their e-preferred profile the publishers whose average delay is longer than the library's on-hold period, as books from these publishers would frequently end up waiting for the entire on-hold period before being shipped in print.

It should also be noted that the data here do not necessarily reflect the publishing industry as a whole, as they only include publishers that were on Temple University's e-preferred profiles. This could skew the data toward showing a higher percentage of e-book availability than in the industry as a whole, as they exclude publishers that are not as likely to produce e-books. However, even more of the books in this dataset might exist in e-book form than what is shown here. Some publishers are either offering e-books only on their own platforms, or offering them first on their own platforms and only later in aggregators. ${ }^{45}$ Still others offer their e-books through a different aggregator, such as EBSCO. Link's study of the holdings of The College of New Jersey in 2012 found that only 8 percent were available in MyiLibrary; but, if the search were broadened to include all major e-book aggregators, availability increased to 17 percent. ${ }^{46} \mathrm{With}$ these limitations, this study still provides an example to add to librarians' understanding of publication patterns. The data show how delays can vary by title, even with books from the same publisher, and how Coutts' profiling process affects availability. If a similar study were done in the near future at a library that uses a different vendor or different e-book platforms, those findings could be reviewed together with the current study to create a fuller picture of the e-book market for libraries. Since the e-book publishing industry is still changing, any study done two or three years from now would more appropriately be compared to this rather than aggregated with it. For e-books, two or three years may be a sufficient gap for those who want to look at changes over time.

\section{Conclusion}

Publishing e-books simultaneously with print is still not the norm, despite some publishers' stated intentions; thus, deciding what to do about delays is still an issue for libraries. This analysis of publication patterns can better equip libraries to make decisions about how long they will wait to see if an e-book becomes available. This study shows that, the older a print book gets, the more likely it is to have an electronic version, but that the largest gains in e-book availability come during the first few weeks after the print publication. Waiting for an e-book becomes less worthwhile the longer the wait. While 47.85 percent of books are available as e-books fourteen days after print, it is not until day 101 that the percentage tops 75 percent. Libraries wishing to review their wait periods based on the data provided here will most likely choose a wait period between eight and thirty-six days. After thirty-six days, continuing to wait is usually not worthwhile unless a particular school or program has such a strong preference for e-books that print is not considered to be useful. Each library's decision can be based on a combination of data and situational preferences, and a library can set a different wait period for each subject profile in the approval plan.

Though the optimal on-hold period for an e-preferred approval plan cannot be determined by numbers alone, the data provided here can be a significant piece of the decision-making process. The patterns shown here can allow librarians to qualify Buckley and Tritt's statement that "Unless simultaneous publishing becomes an industry standard for publishers, the full potential of an ebook approval plan is limited." ${ }^{17}$ 
While it is not possible to buy everything in e-book form, libraries can still use e-book approval plans judiciously. Certainly the variation in publication schedules makes purchasing complicated for libraries, as does the scarcity of analyses of publication patterns. Though exact predictions of e-book release dates are still not possible, knowledge of patterns allows librarians to build electronic collections wisely.

\section{Acknowledgement}

Many thanks to Mary Lynn Kingston of ProQuest Coutts for several hours spent teaching me how to use OASIS to collect these data and answering questions about OASIS.

\section{Notes}

1. William H. Walters, "E-books in Academic Libraries: Challenges for Acquisition and Collection Management," portal: Libraries \& the Academy 13, no. 2 (2013): 187-211.

2. Nancy K. Herther, "21st-Century Lending Libraries," Searcher 19, no. 7 (2011): 14.

3. Suzanne M. Ward, Robert S. Freeman, and Judith M. Nixon, introduction to Academic Ebooks: Publishers, Librarians, and Users (West Lafayette, Ind.: Purdue University Press, 2016), 1-16.

4. Rhonda Herman, "The Journey beyond Print: Perspectives of a Commercial Publisher in the Academic Market," in Academic E-books: Publishers, Librarians, and Users, eds. Suzanne M. Ward et al. (West Lafayette, Ind.: Purdue University Press, 2016), 35-49.

5. Ward, Freeman, and Nixon, introduction to Academic E-books, 1-16.

6. Steven A. Knowlton, "Print, Electronic, or Both? How Libraries Choose a Format When Purchasing Books," Tennessee Libraries 64, no. 2 (2014), available online at http://www.tnla. org/?page=TL64_2_formats [accessed 30 September 2016].

7. ProQuest, "Academic Library Book Purchasing Trends" (2016), available online at http:// contentz.mkt5049.com/lp/43888/438659/D187_Ebooks_Aquisition_whitepaper_v5.pdf [accessed 13 April 2016].

8. Dracine Hodges, Cyndi Preston, and Marsha J. Hamilton, "Resolving the Challenge of E-books," Collection Management 35, no. 3/4 (2010): 196-200; Carmelita Pickett, Simona Tabacaru, and Jeanne Harrell, "E-approval Plans in Research Libraries," College E Research Libraries 75, no. 2 (2014): 218-31.

9. Pickett, Tabacaru, and Harrell, "E-approval Plans in Research Libraries," 218-31.

10. Knowlton, "Print, Electronic, or Both?"; Pickett, Tabacaru, and Harrell, "E-approval Plans in Research Libraries," 218-31.

11. Kizer Walker, "Patron-Driven Acquisition in US Academic Research Libraries: At the Tipping Point in 2011?" Bibliothek Forschung und Praxis, 36, no. 1 (2012): 126-30.

12. Ward, Freeman, and Nixon, introduction to Academic E-books, 1-16; Knowlton, "Print, Electronic, or Both?"; Sarah Pomerantz, "The Availability of E-books, Examples of Nursing and Business," Collection Building 29, no. 1 (2010): 11-14.

13. Walters, "E-books in Academic Libraries," 187-211.

14. Ibid.

15. Jennifer O. Yao, "Art E-Books for Academic Libraries: A Snapshot," Art Documentation: Journal of the Art Libraries Society of North America 33, no. 1 (2014): 27-40.

16. Craig Anderson and Jeanie Pham, "Practical Overlap: The Possibility of Replacing Print Books with E-Books," Australian Academic E Research Libraries 41, no. 1 (2013): 40-49.

17. Ward, Freeman, and Nixon, introduction to Academic E-books, 4.

18. Gabrielle Wiersma, "What's the Delay? Managing E and P Publication Dates," Library Collections, Acquisitions, E Technical Services 37, no. 1/2 (2013): 13-18.

19. Ibid.

20. Herther, "21st-Century Lending Libraries," 14. 27-34.

21. Michael Zeoli, "Supplying and Collecting Books," Library Technology Reports 51, no. 8 (2015):

22. Wiersma, "What's the Delay?" 13-18.

23. Hodges, Preston, and Hamilton, "Resolving the Challenge of E-books," 196-200.

24. Michael Levine-Clark, "Electronic Books and the Approval Plan: Can They Work Together?" Against the Grain 19, no. 2 (2007): 18.

25. Tony Sanfilipo, "Production, Marketing, and Legal Challenges: The University Press Perspective on E-Books in Libraries," in Academic E-Books: Publishers, Librarians, and Users, eds. Suzanne M. Ward et al. (West Lafayette, Ind.: Purdue University Press, 2016), 51-62. 
26. Ward, Freeman, and Nixon, introduction to Academic E-Books: Publishers, Librarians, and Users, 1-16; Wiersma, "What's the Delay?" 13-18.

27. Zeoli, "Supplying and Collecting Books," 27-34.

28. Herman, "The Journey Beyond Print," 35-49; Sanfilipo, "Production, Marketing, and Legal Challenges," 51-62.

29. Sanfilipo, "Production, Marketing, and Legal Challenges," 51-62.

30. Herman, "The Journey Beyond Print," 35-49.

31. ProQuest, "Academic Library Book Purchasing Trends."

32. Pickett, Tabacaru, and Harrell, "E-approval Plans in Research Libraries," 219.

33. Arlene Moore Sievers-Hill, "Building Library Collections in the 21st Century: How Goes the Book Approval Plan in the Days of the Ebook?" Against the Grain 22, no. 6 (2010): 73.

34. Sarah Forzetting, Gabrielle Wiersma, and Leslie Eager, "Managing E-book Acquisition:

The Coordination of ' $\mathrm{P}$ ' and ' $\mathrm{E}$ ' Publication Dates," Serials Librarian 62, no. 1/4 (2012): 200-05.

35. Levine-Clark, "Electronic Books and the Approval Plan," 18-22.

36. Wiersma, "What's the Delay?" 13-18.

37. Ibid.

38. “Temple University Libraries Strategic Plan 2009-2012," last modified January 14, 2014, http://library.temple.edu/sites/default/files/strategicplan.pdf [accessed 8 January 2016].

39. Wiersma, "What's the Delay?" 13-18.

40. Ann Roll, "Both Just-In-Time and Just-In-Case: The Demand-Driven-Preferred Approval Plan," Library Resources \& Technical Services 60, no. 1 (2016): 4.

41. Zeoli, "Supplying and Collecting Books," 27-34.

42. Walters, "E-Books in Academic Libraries," 187-211.

43. Forzetting, Wiersma, and Eager, "Managing E-book Acquisition," 200-05.

44. Wiersma, "What's the Delay?" 13-18.

45. Pickett, Tabacaru, and Harrell, “E-approval Plans in Research Libraries," 218-31.

46. Forrest E. Link, "Are We There Yet? An Analysis of E-Book Equivalent Coverage in Highly Circulated Titles at The College of New Jersey Library," Collection Building 31, no. 4 (2012): 132-35.

47. Matthew Buckley and Deborah Tritt, "Ebook Approval Plans," Computers in Libraries 31, no. 3 (2011): 15-18. 